\title{
NOTES
}

\section{ARVIDA AND THE SEC: PREFILING PUBLICITY}

To protect the unwary public against prejudicial misrepresentations, the Securities Act of $1933^{1}$ requires that issuers and underwriters make "full disclosure" to prospective investors of all facts concerning offerings of new issues of securities traded in interstate commerce. The Act further provides that it is unlawful to use the instruments of interstate commerce to "offer to sell" any security unless and until the security has first been registered with the Securities and Exchange Commission," and defines "offer to sell" to include an offer to dispose of, or a solicitation of an offer to buy, a security. ${ }^{3}$ An extremely vexing and unsettled question arising from these provisions is the extent to which an issuer or its underwriters, ${ }^{4}$ prior to fling a registration statement, may publicize

\footnotetext{
${ }^{i}$ Securities Act of 1933, 48 Stat. 74 (1933), 15 U.S.C. $\$ \$ 77 a-77 z$ (1952), as amended, 68 Stat. 683 (1954), 15 U.S.C. $\$ \$ 77 \mathrm{~b}-77 \mathrm{v}$ (Supp. V, 1958). For discussion of various aspects of the disclosure provisions, see generally LOSS, SECURITIES REcULATron 5-6, 77-82 (I951); MacChesney \& O'Brien, Full Disclosure under the Securities $A c t,+$ LAW \& CONTEMP. Prob. 133 (1937); Goldschmidt, Registration tunder the Securities Act of r933, + LAW \& CONTEMP. ProB. I9 (1937).

${ }^{2}$ Section 5 (c) of the 1933 Act provides, "It shall be unlawful for any person, directly or indirectly, to make use of any means or instruments of transportation or communication in interstate commerce or of the mails to offer to sell or offer to buy through the use or medium of any prospectus or otherwise any security, unless a registration statement has been filed as to such security, or while the registration statement is the subject of a refusal order or stop order or (prior to the effective date of the registration statement) any public proceeding or examination under Section $77 \mathrm{~h}$ of this title [section 8]." Securities Act of $1933 \$ 5$ (c), 68 Stat. 684 (1954), 15 U.S.C. $\$ 77$ (Supp. V, 1958 ), amending 48 Stat. 906 (1933), 15 U.S.C. $\$ 77$ (1952).

${ }^{3}$ Securities Act of 1933 \& $2(3), 48$ Stat. 74 (1933), 15 U.S.C. $\$ 77 b(3)$ (1952), as amended, 68 Stat. 683 (1954), 15 U.S.C. \& $77 b(3)$ (Supp. V, 1958). Although $\$$ $2(3)$ has wide scope, it excludes from the definition of "offer" all preliminary negotiations between an issuer and any underwriter, or among underwriters who are in privity of contract with an issuer. For other specific exemptions, see Securities Act of 1933, $\$ \S 3,4,48$ Stat. 75,77 (1933), I5 U.S.C. $\$ \S 77 \mathrm{c}, \mathrm{d}(1952)$, as amended, 68 Stat. 684 (1954), 15 U.S.C. $\$ \$ 77 c, d$ (Supp. V, 1958).

"The term 'issuer' means every person who issues or proposes to issue any security. ..." Securities Act of 1933, $\S_{2}(4), 48$ Stat. 74 (1933), 15 U.S.C. $\S 77 b(4)$ (1952). "The term 'underwriter' means any person who has purchased from an issuer with a view to, or offers or sells for an issuer in connection with, the distribution of any security, or participates or has a direct or indirect participation in any such undertaking...." Securities Act of $1933 \$ 2$ (II), 48 Stat. 74 (1933), 15 U.S.C. $\$ 77$ b(11) (1952), as amended, 68 Stat. 683 (1954), 15 U.S.C. $\$ 77 \mathrm{~b}$ (11) (Supp. V, 1958).
} 
information which may tend to arouse the interest of prospective investors in a forthcoming issue of corporate securities. Such a problem was posed recently in the interrelated cases of $S E C$ v. Arvida Corp. ${ }^{5}$ and In the Matter of Carl M. Loeb, Rhoades and Co. and Dominick and Dominick. ${ }^{6}$

In the Arvida case, two managing underwriters had agreed to underwrite a public offering of $\$ 25,000,000$ to $\$ 30,000,000$ of Arvida stock, the proceeds from which were to be used in the development of Arthur Vining Davis' vast real estate holdings in southeastern Florida. ${ }^{7}$ Before filing a registration statement with the SEC, the underwriters prepared and issued a press release ${ }^{8}$ announcing the proposed offering of common stock to the public, the plans for the development of the property, and the nature and extent of the assets of the new corporation. At a press conference held concurrently with the distribution of the prepared release to several prominent New York newspapers, the underwriters disclosed, in response to the questioning of reporters, the proposed offering price of the stock. It was further stated that a securities registration statement was being prepared. ${ }^{9}$

Shortly after publication of the press release and the correlative news stories, the SEC sought to enjoin further similar releases, ${ }^{10}$ alleging that the announcements by the underwriters amounted to an "offer to sell"

"I69 F. Supp. 211 (S.D.N.Y. 1958).

${ }^{\circ}$ SEC Securities Exchange Act Release No. 5870, February 9, 1959, CCH FED. SEC. L. REP. I 76,635 (1959), [hereinafter referred to as Release 5870$]$.

${ }^{7}$ Mr. Davis transferred over 100,00o acres, or more than 155 square miles, of land to the Arvida Corporation for development. Some of the land, however, was under the minimum flood level. See Arvida Corporation Final Prospectus.

${ }^{8}$ The press release emphasized the addition to the capital of Arvida of $\$ 25,000,000$ to $\$ 30,000$, ooo through the proposed offering, the increase in the total assets of the corporation by virtue of Davis' trausfer of more than $\$ 100,000,000$, the names of the underwriters for the offering and the officers of the corporation, the fact that a registration statement to be filed with the SEC was in preparation, the extent and location of the land holdings of the corporation, and the general objectives of the corporation's development program. SEC v. Arvida Corp., 169 F. Supp. 211, 213, 214 (S.D.N.Y. 1958).

Id. at 214 .

${ }^{10}$ Section 20 (b) of the Securities Act of 1933 provides that the Commission may apply to a federal district court for au injunction if any person is engaged or is about to engage in any practices constituting a violation of that Act. Although the SEC immediately obtained a temporary restraining order, it was vacated within two hours by the Second Circuit Court of Appeals, Arvida Corp. v. Sugarman, 259 F.2d 428 (2d Cir. 1958). Subsequently, its motion in the district court for a temporary injunction was also denied, as was the defendants' cross-motion for disınissal. SEC v. Arvida Corp., CCH FED. SEC. L. REP. I 90,883 (1958). 
before registration, in violation of section 5 (c) of the 1933 Act. Simultanecusly, the SEC instituted proceedings to revoke the broker-dealer registration of the two managing underwriters, pursuant to section I 5(b) of the Securities and Exchange Act of $1934^{11}$

The SEC argued in both cases that the press release was, in essence, the launching of a sales campaign prior to the filing of the required registration statement with the Commission. ${ }^{12}$ The underwriters demurred, however, insisting that the release was intended merely to dispel rumors concerning the liquidation of Mr. Davis' holdings. After extensive negotiation, a consent decree emerged permanently restraining the underwriters from "offering" any Arvida securities before the filing of a registration statement. ${ }^{13}$ The court recognized that although the underwriters may have acted in good faith, their action, nevertheless, viclated section 5 (c) of the 1933 Act. ${ }^{14}$ As part of the over-all disposition, the SEC proceedings against the underwriters were terminated without sanction. However, in Release No. 587o, the Commission announced its findings that the Act had in fact been violated. ${ }^{15}$

Section 5 puts teeth into the provisions of the 1933 Act regulating disclosure, and a broad construction of its terms has been found to be

${ }^{12}$ Section ${ }_{15}$ (b) of the Securities Exchange Act of 1934 provides: "The Commission shall, after appropriate notice and opportunity for hearing, by order deny registration to or revoke the registration of any broker or dealer if it finds that such denial or revocation is in the public interest and that ... such broker or dealer ... has wilfully violated any provision of the Securities Act of $1933 \ldots$ or of any rule or regulation thereunder." ${ }_{4} 8$ Stat. 895 (1933), 15 U.S.C. $\$ 780$ (b) (1952).

${ }^{12}$ Brief for Plaintiff, p. I8, SEC v. Arvida Corp., I69 F. Supp. 211 (S.D.N.Y. 1958), Release 5870, CCH FED. SEC. L. REP., supra note 6, at 80,427. This conduct is termed "beating the gun." The purpose is to avoid the Securities Act by obtaining from dealers "indications of interest" tantamount to orders to buy. The dealers, in turn, solicit the same statements from their customers. Thus, each subsequent selling group minimizes the possibility of loss, since the entire issue is placed before title has moved from one group to another. The result is that the investor usually is highpressured into buying a security without any substantial information as to its value. Although this type of scheme does not utilize any legal sanctions to enforce it, a dealer who does not later adhere to his commitment might well be ignored by the industry in a future offering, resulting in loss of profit as well as institutional reputation. The Commission has properly deemed any such accelerated distribution to be a violation of $\S 5$ of the Securities Act of 1933. Van Alstyne, Noel and Co., 22 S.E.C. 176 (1946), 1945-47 CCH FED. SEC. DEC. T75,636 (1946). For detailed discussions of the problem see Loss, Securities Regulation 161-66 (195I); Byse \& Bradley, Proposals to Amend the Registration and Prospectus Requirements of the Securities Act of 1933,96 U. PA. L. REv. 609, 621 (194\$).

${ }^{13}$ SEC v. Arvida Corp., 169 F. Supp. 211 . (S.D.N.Y. 1958).

14 Id. at 215 .

${ }^{15}$ Release 5870, CCH FED. SEC. L. REP, supra note 6 , at 80,427 . 
necessary to cope with various prefiling publicizing techniques which violate the spirit of the Act. ${ }^{16}$ In past years, the courts have employed this section to enjoin advertisements pertaining to securities offerings. ${ }^{17}$ Similarly, in the leading case involving prefiling violations, Van Alstyne, Noel and $\mathrm{Co} .{ }^{18}$ publicity releases in newspapers, coupled with elaborate communications with dealers designed to ascertain interest in a particular issue, were held to constitute an offer under section 5(c). It has also been held that a direct solicitation of offers through a newspaper rendered the issuer a "seller" under the Act. ${ }^{19}$

In contrast, however, section 5 (c) had never been interpreted to proscribe newspaper articles initiated by reporters, even though the articles pertained to proposed offerings and were published in the prefiling period. ${ }^{20}$ Nor has that section apparently been invoked to prevent customary. institutional or business-products advertising not relating directly to a proposed issue of the advertiser. ${ }^{21}$ Similarly, financial circles had assumed that issuers and underwriters could properly provide the public with a substantial amount of information concerning business developments and securities matters through the press, even though the releases referred to proposed offerings. ${ }^{22}$

Perhaps due in part to the enormous public clamor incident to the Ford offering in $1956,{ }^{23}$ when investor excitement caused the stock to trade up to a twenty-point premium before falling below the price at

${ }^{10}$ See SEC v. Chinese Consolidated Benevolent Ass'n, Inc., 120 F.2d 738 (2d Cir. 1941) (publicity by advertising in newspapers, mass meetings, and personal appeals); see also Loss, SECURITIES REgulation 141 (1951), for discussion of "institutional advertising."

${ }^{17}$ SEC v. Starmont, 3 I F. Supp. 264 (E.D. Wash. 1940) (high-pressured solicitations of stock subscriptions).

${ }_{18} 22$ S.E.C. 176 (1946), 1945-47 CCH FED. SEC. DEC. I 75,636 (1946).

${ }^{10}$ SEC v. Bailey, 4I F. Supp. 647 (S.D. Fla. 1947); SEC v. Tung Corp. of America, 32 F. Supp. 371 (N.D. Ill. 1940).

${ }^{20}$ Release 5870, CCH FED. SEC. L. REP., supra note 6, at 80,432. However, it appears that any advertisements or other illegal announcements that are paid for by the issuer, underwriter, or dealer, directly or indirectly, render the communication medium involved liable as aiding the violation. Loss, SEcurimes REGULATion 138 (1953).

${ }^{27}$ Gadsby, Current Problems under Section 5 of the Securities Act of 1933 and Release No. 3844, 13 Bus. Law. 358, 362 (1958): "Most certainly an issuer may continue the normal conduct of its business and may communicate with its security holders and customers prior to the filing of a registration statement. ..."

${ }^{23}$ For instances of extensive publicity concerning proposed offerings where the SEC chose not to interfere, see SEC: Caveat Emptor, 58 Fortune 340 , Nov, 1958. See also note 30 , infra.

${ }^{23}$ Business Week, Sept. 27, 1958 , p. 146. 
which it was offered, there has been a noticeable toughening of the attitude of the SEC toward all prefiling activity. For example, the apparent purpose of one of the Commission's recent statements of policy, Securities Act Release No. $3844^{24}$ was to announce the broad principles to be applied in determining the existence of an offer. Theretofore, no such detailed principles had been articulated. Each case was decided on an ad hoc basis, and the SEC apparently was disposed to discipline none but the most flagrant violators. ${ }^{25}$ Under Release 3844 , however, the conduct which may be deemed an offer includes all publicity efforts prior to a proposed financing which, although not couched in terms of an express offer, may, in fact, tend to arouse public interest in the issuer. ${ }^{28}$ Furthermore, the opinion in the SEC proceeding concerning the underwriters of the Arvida issue, Release 5870, concludes that publicity "with respect to an issuer or its securities, emanating from ... underwriters . . must be presumed to set in motion or to be a part of the distribution process and therefore to involve an offer to sell. .... .

Notwithstanding Release 3844; Chairman Gadsby has stated that the policy of the Commission is somewhat more liberal than would seem to be indicated. Thus, he has declared that an issuer may continue to publish advertisements of its products and services without interruption,

\footnotetext{
${ }^{26}$ SEC Securities Act Release No. 3844, 1 CCH FED. SEC. L. REP. I 2291 (1957), [hereinafter referred to as Release 3844 ].

${ }^{25}$ See note 22 supra. "The fact is that all through the history of the rulings of the Commission in dealing with this question runs a consistent and simple logic. If the material submitted is reasonably to be considered as a part of the selling effort, it comes within the purview of the statute. If not, then it is none of our business. The ultimate determination must be made on an ad hoc basis, and we must invoke the exercise of judgment in evaluating matters of degrees." Gadsby, supra note 21 , at 367 .

${ }^{20}$ In its Release 3844 , the Commission presents a series of examples indicating various information releases it considers violative of the Act, including the following: (1) When, during the prefiling period, an issuer and a prospective underwriter arrange for a series of press releases describing the activities of the company, its poposed program of development of its properties, estimates or reserves and plans for a processing plant; (2) When a research department of an investment banking firm, unaware that its underwriting department is planning a new issue for an industrial company, distributes to a number of the firm's customers a brochure referring to the securities and business prospects of the issuing company; (3) When, long in advance of a proposed securities offering, a corporate officer is scheduled to deliver an address to a group of security analysts, the speech may be presented although it includes the record, problems, operations, future growth and future profits of the speaker's company, but printed copies of the talk may not be distributed at the meeting and by mail to selected interested parties. Release 3.844, I CCH FED. SEC. L. REP. I 2291 (1957).

${ }^{27}$ Release 5870, CCH FED. SEC. L. REP., supra note 6, at 80,431 (1959).
} 
may send its regular financial reports to its security holders, and may make "routine" announcements to the public press. As to underwriters, however, the Chairman emphasized a distinction unmentioned in Release 3844: An underwriter may not engage in publicity with respect to an issuer at a time when transactions in the security would be prohibited. Summarizing, Chairman Gadsby noted that "intent, knowledge and time" are important factors in determining whether a selling effort has been commenced. ${ }^{28}$

Although the Arvida cases appear, at first glance, to comport with this articulated policy, ${ }^{29}$ the contrary may be urged with some force and cogency. In absence of actual intent to commence a selling campaign, it would seem logically to follow that no offer of securities could possibly be found. In the Arvida case, however, where there was some evidence that the announcement was necessary and in the public interest at the time it was released, ${ }^{30}$ the SEC stipulated that the underwriters had had no intention of violating the Securities Act. ${ }^{31}$ Yet, in the SEC proceed-

${ }^{28}$ Gadsby, supra note 21 , at 362 .

${ }^{20}$ Ibid. In addition to the criteria mentioned by Chairman Gadsby, Release 3844 adds that news releases tending to "condition" the public mind in favor of the issuer's securities will be deemed to show the commencement of a sales campaign. Release 3844 , I CCH FED. SEC. L. REP. I 2291 (1957).

${ }^{30}$ The underwriters contended that the announcement was made in the public interest, due to the concern of the public and the financial fraternity over the land values as a result of the unfounded rumors of the possible sudden liquidation of Davis' holdings. Although affidavits of public officials and prominent citizens were submitted to support this argument, the Commission dispensed with it in a footnote, finding that the detailed information in the press release would not be needed merely to dispel the alleged rumors. Release 5870, CCH FED. SEC. L. REP. I 76,635 n. I7 (1959). The SEC also pointed out that any public concern over the liquidation of the Davis holdings should have been quieted by an earlier press release, issued in Florida, announcing the trausfer of Davis realty to Arvida Corporation. Id. at 80,43 I.

The underwriters also argued that the SEC should not be allowed to attack the propriety of the press release since the prior inaction of the SEC toward the common practice of announcement of proposed offerings before filing indicated that such announcements were proper under the Commission's existing criteria. The underwriters pointed to 31 such announcements appearing in the Commercial and Financial Chronicle from January to September, 1958. The text of one example, from the April 3, 1958 , issue of that publication reads:

"One William Street Fund, Inc. April 2 it was reported this Fund expected in the very near future to register with the S.E.C. an issue of $3,000,000$ shares of capital stock. Price-\$12.50 per share. Proceeds-for investment. Underwriter-Lehman Brothers, New York. Offering-expected in May." Brief for Defendants, pp. 18, 19, SEC v. Arvida Corp., 169 F. Supp. 2 I 1 (S.D.N.Y. 1958).

${ }^{31}$ Finding of Fact No. 18, SEC v. Arvida Corp., 169 F. Supp. 211,214 (S.D.N.Y. 1958). 
ings, the Commission seems to have found an intent to commence a sales campaign. ${ }^{32}$ Even admitting the possibility that the SEC had decided to horse-trade various points in arriving at an acceptable consent decree, it is difficult to understand the Commission's conceding the "intent" point if it was crucial to finding an offer in the SEC proceeding. ${ }^{33}$ Thus, in comparing the consent decree with Release 5870 , it is possible to conclude that a finding of intent is unnecessary when the result of the acts is naturally to stimulate offers to purchase. But query: May an underwriter adduce enough evidence to show a legitimate nonselling purpose in making a press release and still be said to have offered securities for sale? Is there one standard for an injunction and another for a dealer-registration revocation? ? $^{34}$

There is an explanation which would reconcile the two Arvida cases, but it would force the conclusion that Commission has departed from the policy announced in Release 3844 and the speeches of Chairman Gadsby. In Release 5870, the Commission has stated that prefiling "publicity ... with respect to an issuer" is presumptively an offer. ${ }^{35}$ If "publicity" be given its broadest meaning, any statement by an underwriter with respect to an issuer would constitute an offer, and any subjective test, such as intent, would be rendered irrelevant. ${ }^{38}$ In the Matter of the

${ }^{32}$ The rationale of the Commission seems to rest largely on the effect of the anmouncement upon investors' interest. A survey conducted by the SEC during a two-day period discovered buying interest by brokers, dealers, and the investing public in the Arvida stock totaling over $\$ 500,000$ as a direct result of the publication. The underwriters received inquiries concerning participation in the offering from ${ }_{4} 45$ securities firms. SEC v. Arvida Corp., 169 F. Supp. 2xx, $2 \times 4$ (S.D.N.Y. 1958).

${ }^{33}$ Even within Release 5870 the SEC confuses the question of intent. In Release 5870 , CCH FED. SEC. L. REP., supra note 30 , at n. 21 , it is stated that the Commission did not find that the underwriters intended to violate the law, but in the text of that Release, at $\mathrm{n}$. 16, the Commission finds that the underwriters intended to start a sales campaign, thus intending to violate the Act.

${ }^{34}$ This is certainly arguable. See Release 5870, CCH FED. SEC. L. REP., supra note 30 at $n .21$, where the Commission says, "a finding of willfulness within the meaning of [the broker-dealer registration sections] does not require a finding of intention to violate the law."

st "We accordingly conclude that publicity, prior to the filing of a registration stateinent ... with respect to an issuer or its securities, emanating from ... underwriters ... must be presumed to set in motion or to be a part of the distribution process and therefore to involve an offer to sell or a solicitation of an offer to buy such securities prohibited by Section $5(\mathrm{c})$." Id. at $80,43 \mathrm{x}$.

${ }^{30}$ See the examples of the SEC's concept of "publicity" in note 26, supra. As a recent editorial has phrased it, "Without announcing any formal change in rules, SEC has gradually broadened its definition of an 'offer to sell' until it covers even such seemingly innocent things as a handout from the publicity department or a speech by the 
First Maine Corp., ${ }^{37}$ an SEC proceeding for suspension of a dealer from the National Association of Securities Dealers, decided by the Commission after Matter of Carl M. Loeb, Rhoades and Co. and Dominick and Dominick, it was held that such a presumption would apply. This ruling seems to lend weight to the supposition that the Commission rested heavily upon the same presumption in the Arvida proceedings. But if this was the rule applied in the Arvida proceedings, it bespeaks an unusual notion of fair play, since, before Aroida, no such test had been employed or even intimated by the Commission in ascertaining the existence of a prefiling offer. ${ }^{38}$ And even if this ruling defines the bounds of propriety for underwriting publicity, query: Do they obtain as well for issuers?

More fundamentally, perhaps, there exists the question whether the "new" policy of the SEC has outdistanced congressional intent. ${ }^{39}$ The clear and legitimate effect of aggressive enforcement of the Securities Acts by the SEC is preclusion of prefiling publicity dedicated to sales campaigning. But if this "new" policy will preclude any prefiling activity by the underwriters and allow but little more by the issuer, its social utility may be questioned. While the SEC has presented an array of

company president." Business Week, Dec. ${ }_{13}, 1958$, p. 28. The Commission's chairman appears to regard as prohibited publicity "public communications of various sorts ... which discuss such aspects of a business as its finances, its earnings or its growth prospects in glowing and optimistic terms." Gadsby, supra note 21, at 362 .

${ }^{87}$ SEC Securities Exchange Act Release No. 5898, CCH FED. SEC. L. REP. I 76,642 (1959). In this case, the SEC sought to revoke the broker-dealer registration of the First Maine Corporation for violating 5(b) of the Securities Act of 1933 in distributing mail circulars, advertisements and notices to brokers, dealers, insurance agencies, and a newspaper. Although none of these contained any words of offer, the SEC found a violation of the Act. Notwithstanding that the absolute presumption of an offer was reaffirmed by the Commission, it went out of its way to point out that the presumption would "not necessarily" be applied when broker-dealers incidentally mention an issuer or a security in financial information commonly furnished to customers and prospective customers in the ordimary course of business. It may be that this statement indicates that the Commission's position is not so inflexible as Release 5870 implies.

${ }^{38}$ See note 25 supra.

${ }^{30}$ Although the expressed purpose of the Securities Act of 1933 is to close the channels of commerce to security issues until full disclosure of the character of such securities has been made, a further purpose, as phrased by the President and apparently endorsed by Congress, is "to protect the public with the least possible interference to honest bsuiness." H.R. REP. No. 85, 73d Cong., 1st Sess., 2, 3 (1933). See also S. REP. No. 1036, 83d Cong., 2d Sess., 4-6 (1954), and H.R. ReP. No. 1542, 83d Cong., 2d Sess., 10-13 (1954), where earlier dissemination of information to the public is encouraged by allowing offers during the "waiting period" between filing and the effective date of registration. 
logical arguments showing the need for prefiling silence, ${ }^{40}$ at least one interested group, the financial press, has taken vigorous exception to that position, urging that such gagging is not only violative of the legislative scheme, but also unnecessary and oppressive to both the issuer and the press. ${ }^{41}$

Notwithstanding the SEC's exegesis of the Securities Acts, there appear to be at least three situations in which, by common standards of fairness, the publisher of a statement should not be open to censure by the Commission, but where Release 5870 would seem to construe an offer.

Suppose that an issuer has seldom advertised. Suddenly, two weeks prior to the date on which the company expects to market its new security, many advertisements booming its product appear in newspapers and magazines throughout the country. While no reference has been made to the securities offering, the mere exposure of the public to the advertisement could, under the recent SEC release, be said to constitute such a "conditioning of the public mind" to purchase the issuer's securities sufficient as to amount to an offer. If such an interpretation were placed upon institutional or business-products advertising, few would

${ }^{10}$ The SEC relied upon three arguments in urging that prefiling publications should be stopped: ( 1 ) dissemination of information before fling may create an artificial demand for a security and, in effect, accomplish its sale before registration; (2) misleading communications could be made with impunity under the Act, if such information releases are not considered offers; and (3) if prefiling silence is not maintained, a constant stream of cleverly disguised information could easily circumvent the purpose of $\S$ 5. Brief for SEC, pp. 30-32, SEC v. Arvida Corp., I69 F. Supp. 2 I I (S.D.N.Y. $1958)$.

12 In a recent bitter editorial, the SEC is accused of muzzling the press through indirect methods and challenged to show that Congress "intended to make it the sole channel through which information about new securities could be communicated to the public." Business Week, Dec. 13, 1958, p. 140. Interestingly enough, that journal also reported that it had researched and completed an article concerning the general operations of an important company which had a security offering in preparation. After the Aroida decisions, the company "urgently requested that the whole project be dropped ... [because the company's] lawyers advised it that the only safe policy was to see to it that no articles about the company appeared in the press until after the issue was sold." Business Week, Dec. 13, 1958, pp. 28, 29. Other financial journals also have reported that the Commission's action will stop legitimate news releases, Forbes, Business and Finance, Jan. 15, 1959, p. 15, a criticism the Commission has shrugged off with the comment that it has no interest in what the press may choose to publish so long as those contemplating new issue of securities make no press release constituting an offer to sell securities. Business Week, Dec. 13, 1958, p. 28, col. I. See also $S E C$ : Caveat Emptor, 58 Fortune 140, 143, Nov. 1958. But see the SEC's reply in Release 5870 , CCH FED. SEC. L. REP., supra note 30 at 80,432 n. 19. 
deny that any "conditioning of the public mind" had become a meaningless standard.

Secondly, assuming arguendo that an underwriter or issuer, as in the Aroida case, was, in fact, concerned about rumors which might adversely and substantially affect the stability of an area's economy, it would seem that the release of mollifying information would be likely to have a very socially desirable effect. If it is possible to attribute such an altruistic motive to an underwriter or issuer, then, it would actually be inconsistent with Congress' statutory mandates for the SEC to prohibit such activity, provided the announcement does not disseminate puffing details of the financial structure of the corporation, as perhaps occurred in the Aroida case. ${ }^{42}$

Finally, if, as contended in the Arvida case, the motive in publishing the release was to bolster the confidence of the public in a corporation and thus to save the underwriters and the corporation from an otherwise unavoidable heavy loss, ${ }^{43}$ it would also seem unfair to prohibit the announcement. Even assuming that the preliminary prospectus contained a glowing report on the finances and management of the company, a possible loss still might not be averted, since the prospectus is notoriously complex, unreadable and unread by the public. It appears that the SEC's policy should be realistic enough and flexible enough to permit such an announcement related to the rumor and so long as no details of the corporation's finances and no misstatement of fact were made.

It seems fair to conclude that the Aroida cases have produced an amorphous standard to regulate an activity of vital concern to the financial institutions of this country. Since SEC sanctions compel respect of this standard, the result, whether or not intended, is to stifle, without discrimination, the publication of both legitimate and illegitimate prefiling information-an effect of dubious legitimacy.

${ }^{49}$ See note 39 supra; see also, Brief for Defendant, p. 16, SEC v. Arvida Corp., 169

F. Supp. 211 (S.D.N.Y. 1958 ).

${ }^{43} I d$., p. 6. 